\title{
Tantangan dan peluang implementasi pendidikan karakter di SMA keagamaan
}

\author{
Suyuti* \& Prima Yustitia \\ Jurusan Pendidikan Sosiologi, Fakultas Ilmu Sosial, Universitas Negeri Jakarta \\ *yuti@unj.ac.id
}

\begin{abstract}
Character education discourse in Indonesia is still an important study that needs to develop along with the emergence of increasingly complex and complicated social problems. This study aims to explain the implementation of character education during the COVID-19 pandemic, in particular about the opportunities and challenges of implementing character education in three religiousbased high schools in East Jakarta. This study uses a descriptive qualitative approach with a case study method. The results of this study indicate that the implementation of character education in the three high schools that became the locus of this research has in common the dominant challenges that emerged during the COVID 19 pandemic, namely order and student discipline in online learning that have not been optimal. Although there are similarities in challenges, each of these schools has differences, especially in terms of efforts to develop character education in each school itself. The difference in efforts to develop character education based on the existence of educational institution resources such as teacher human resources, school finance, technological infrastructure, student readiness and the existence of parental support in each school.
\end{abstract}

Keywords: Education; Character; Religion

\begin{abstract}
Abstrak
Diskursus pendidikan karakter di Indonesia masih menjadi kajian penting yang perlu dikembangkan bersamaan dengan munculnya masalah sosial yang kian kompleks dan rumit. Penelitian ini bertujuan untuk menjelaskan implementasi pendidikan karakter dimasa pandemi COVID 19, khususnya tentang peluang dan tantangan implementasi pendidikan karakter di tiga SMA berbasis keagamaan di Jakarta Timur. Penelitian ini menggunakan pendekatan kualitatif deskriptif dengan metode studi kasus. Hasil penelitian ini menunjukkan pelaksanaan pendidikan karakter di tiga SMA yang menjadi lokus riset ini memiliki tantangan yang dominan muncul dimasa pandemi COVID 19 yaitu ketertiban dan kedisiplinan siswa dalam pembelajaran daring yang belum optimal. Kemudian dalam hal upaya mengembangkan pendidikan karakter di masing-masing sekolah dilatari oleh keberadaan sumber daya lembaga pendidikan seperti SDM guru, finansial sekolah, sara-prasarana teknologi, kesiapan siswa dan keberadaan dukungan orang tua siswa di masing-masing sekolah.
\end{abstract}

Kata Kunci: Pendidikan, Karakter, Keagamaan

Diserahkan: 21-11-2021 Disetujui: 26-12-2021. Dipublikasikan: 27-12-2021

Kutipan: Suyuti, S., \& Yustitia, P. (2021). Tantangan dan peluang implementasi pendidikan karakter di SMA keagamaan. Ta'dibuna: Jurnal Pendidikan Islam, 10(4), 569-582.

doi:http://dx.doi.org/10.32832/tadibuna.v10i4.5888 


\section{Pendahuluan}

Wacana dan praktik pendidikan karakter di Indonesia masih menjadi kajian yang perlu dikembangkan bersamaan dengan munculnya berbagai masalah sosial kemasyarakatan yang kian kompleks dan rumit. Dalam konteks ini, pembangunan karakter bangsa dihadapkan dengan banyak persoalan, dari mulai persoalan ekonomi, politik dan sosial-budaya. Berbagai persoalan tersebut disebabkan oleh banyak faktor, salah satunya dilatari oleh perkembangan masyarakat yang sangat dinamis sebagai akibat dari penetrasi globalisasi dan pesatnya kemajuan teknologi komunikasi dan informasi.

Menguatnya penetrasi globalisasi pada bidang ekonomi membawa andil terhadap bertambahnya jumlah kemiskinan dan pengangguran (Yuniarto, 2016; Siswanto, 2020). Hal tersebut dilatarbelakangi oleh salah satu diktum yang populer tentang pembagian jatah ekonomi yang merembes dari atas ke bawah (trickle-down effect), pada faktanya tidak terjadi sesuai yang diharapkan. Jadi, terdapat kota dengan pembangunan optimal, tetapi ada juga kota yang mengalami ketertinggalan pembangunan dan ketersediaan lapangan kerja yang terbatas, sehingga pengangguran dan kemiskinan jumlahnya terus naik (Jati, 2016).

Pada aspek politik, penetrasi globalisasi menciptakan iklim kehidupan politik yang kontra produktif. Realitas ini dapat dilihat dari adanya korupsi dana bantuan sosial (bansos) untuk masyarakat yang terdampak COVID 19 oleh oknum dari level perangkat desa hingga menteri. Korupsi dana publik tersebut adalah cerminan rendahnya integritas diri, dan kepribadian atau karakter yang tidak bisa membedakan mana kepentingan personal dan mana kepentingan publik.

Kemudian pada aspek sosial dan budaya, globalisasi mempengaruhi nilai solidaritas sosial seperti sikap individualistis, materialistis, hedonistik yang akan berimplikasi terhadap tatanan budaya bangsa seperti berkurangnya rasa kebersamaan, gotong royong, menurunnya solidaritas terhadap sesama, melemahnya toleransi antar umat beragama, pudarnya rasa nasionalisme, narkoba, korupsi yang menjadi-jadi dan menguatnya aksi kekerasan yang mengatasnamakan agama dengan paham radikalisme.

Narasi persoalan di atas menegaskan bahwa penguatan pendidikan karakter masih penting untuk dikembangkan dalam sistem pendidikan formal. Karena dalam konteks kehidupan sekarang ini, pembentukan karakter manusia dilakukan melalui proses belajar. Proses belajar manusia pada faktanya memang tidak hanya terjadi melalui institusi pendidikan an-sich. Tetapi, proses belajar juga dapat berlangsung ketika individu ada di dalam lingkungan keluarga, teman sebaya dan masyarakat luas. Namun, proses belajar yang berlangsung pada institusi pendidikan, utamanya sekolah menjadi media yang efektif dalam membentuk karakter atau kepribadian seseorang. 
Penjelasan di atas dapat dikaitkan dengan gagasan Mutrofin yang mengatakan bahwa sistem pendidikan di sekolah memiliki berbagai kepentingan, salah satunya adalah mengoptimalkan sensitivitas (kepekaan) seseorang pada berbagai persoalan sosial, politik, ekonomi, dan budaya (Mutrofin, 2009; Saihu \& Mailana, 2019). Gagasan ini menegaskan bahwa hadirnya institusi sekolah dengan panduan kurikulum yang memadai merupakan ruang yang efektif untuk melaksanakan proses pembelajaran, khususnya dalam implementasi pembelajaran nilai karakter yang mampu mengarahkan masyarakat pada kehidupan yang lebih baik.

Implementasi pendidikan karakter di lembaga pendidikan bukanlah sebuah studi yang baru, karena kajian pendidikan karakter sebagai sebuah studi telah banyak dilakukan oleh para peneliti sebelumnya. Berdasarkan hasil penelusuran penelitian yang sudah dilakukan sebelumnya, dapat diketahui bahwa kajian tentang pendidikan karakter yang menyentuh persoalan pembelajaran daring cenderung berfokus pada masalah lembar kerja siswa sebagai bahan ajar untuk membentuk karakter, peran orang tua memberikan pendidikan karakter saat siswa belajar di rumah melalui daring, dan kendala dalam membentuk karakter melalui pembelajaran daring tanpa menganalisis lebih jauh terkait tantangan dan peluang yang menyertainya (Winaya, 2020; Agustina, 2020; Kusumaningrum, dkk, 2020; Apriyanti \& Burhendi, 2020; Rosita, 2020). Sedangkan studi yang tidak menyinggung persoalan pembelajaran daring, tetapi studinya memiliki kajian yang sama yaitu menyangkut soal implementasi pendidikan karakter juga hanya berfokus pada upaya revitalisasi pendidikan karakter untuk santri dan mengembangkan model pembelajaran pendidikan karakter dengan basis pembelajaran tatap muka (Ramdliyah, 2020; Yuliana, dkk, 2021).

Hasil kajian studi-studi di atas sebagian besar mengambil locus penelitiannya di sekolah dasar (SD), institusi keluarga, dan perguruan tinggi (universitas). Dengan demikian, locus studi di SMA, khususnya lembaga pendidikan berbasis agama terkesan diabaikan. Padahal jenjang pendidikan SMA, khususnya sekolah berbasis keagamaan merupakan arena pendidikan karakter yang penting bagi seseorang untuk menuju jenjang pendidikan selanjutnya yaitu perguruan tinggi. Oleh sebab itu, penelitian ini bertujuan untuk mendeskripsikan tantangan dan peluang implementasi pendidikan karakter berbasis keagamaan di SMA Al Azhar, SMA Muhammadiyah 11, dan SMA Al Ghurabaa yang terletak di Jakarta Timur.

Penelitian ini menjadi penting dan menarik, karena topik tentang implementasi pendidikan karakter di tiga sekolah berbasis keagamaan di Jakarta Timur dilakukan secara daring. Pembelajaran daring mesti dilakukan secara penuh demi mencegah persebaran COVID 19 di Indonesia yang jumlahnya terus meningkat. Selain itu, riset ini juga merupakan upaya untuk meng-update temuan dan pengetahuan baru yang dapat 
berkontribusi pada pengembangan pendidikan karakter ke depan di masa kehidupan new normal.

\section{Metode Penelitian}

Penelitian ini menggunakan pendekatan kualitatif dengan metode studi kasus. Subyek dalam penelitian ini berjumlah enam informan guru yang terdiri dari dua informan guru di SMA Al Ghurabaa, dua informan guru di SMA Muhammadiyah 11, dan dua informan guru di SMA Al Azhar 19 di wilayah Jakarta Timur. Alasan pemilihan subyek dan locus penelitian di tiga SMA wilayah Jakarta Timur karena bertujuan untuk melihat variasi dan kedalaman data berkaitan dengan tantangan dan peluang pelaksanaan pendidikan karakter secara daring di lembaga pendidikan tersebut. Oleh sebab itu, mereka akan menjadi informan kunci dalam penelitian ini.

Metode pengumpulan data yang dilakukan dalam penelitian ini dibagi menjadi dua bagian. Pertama, yaitu bagian data yang bersifat primer diperoleh melalui pengamatan, wawancara mendalam, focus group discussion (FDG melalui Zoom), yang sifatnya mendukung temuan data kualitatif. Kedua, yaitu bagian data yang bersifat sekunder yang di dapat dari hasil penelusuran penelitian ilmiah, buku dan sumber-sumber pemberitaan online lain yang relevan. Kemudian analisis data dalam penelitian ini dilakukan menurut jenis datanya masing-masing. Hasil analisis wawancara mendalam diolah dalam matriks dan bagan alir visual. Dengan teknik ini, diperoleh pola atau kecenderungan yang dapat diperbandingkan antara informasi satu informan guru dengan informan yang lain. Sementara hasil analisis data observasi (berupa foto dan catatan lapangan) diperlukan guna melengkapi data primer (hasil wawancara mendalam) maupun data sekunder. Hasil analisis data pengamatan juga berfungsi sebagai penguji keabsahan dan validitas data dari sumber primer dan sumber sekunder.

\section{Hasil dan Pembahasan}

\section{A. Hasil Penelitian}

Dewasa ini lembaga pendidikan berlabel Islam mengalami perkembangan yang signifikan, baik perkembangan akademik maupun non-akademik. Realitas ini dapat dilihat dari keterserapan alumni pada perguruan tinggi negeri papan atas di Indonesia dan banyaknya capaian prestasi peserta didik dalam berbagai ajang kejuaraan, baik pada tingkat lokal, nasional maupun internasional (Lubis, 2008:82; Azra, 2019). Tentunya perolehan prestasi tersebut merupakan cermin dari perbaikan kualitas dan mutu pendidikan umum berbasis keagamaan itu sendiri.

Pendidikan berlabel Islam, seperti halnya SMA berbasis keagamaan yang dikelola di bawah naungan Kementerian Pendidikan Nasional RI semakin popular di kalangan masyarakat. Banyak masyarakat menginginkan anak-anaknya menempuh pendidikan di 
SMA berbasis keagamaan. Realitas ini tentu tidak datang secara otomatis (taken for granted), melainkan hasil dari kemampuan sekolah umum dalam mengubah wajah pendidikannya, yang tidak lagi sekedar mendidik generasi bangsa untuk pintar ilmu umum saja. Tetapi, kelembagaan pendidikan SMA pada masa kini mampu membekali lulusannya dengan karakter religiositas. Pada konteks kekinian, pendidikan karakter berbasis nilai-nilai religiositas yang dikembangkan di sekolah umum berlabel Islam seperti halnya di SMA Al Ghurabaa, SMA Muhammadiyah 11 dan SMA Al Azhar 19 mampu memberikan daya tawar dan image positif lembaga pendidikan tersebut dimata publik.

Secara umum realitas implementasi pendidikan karakter yang dikembangkan di SMA Al Ghurabaa, SMA Muhammadiyah 11, dan SMA Al Azhar 19 yang menjadi locus riset ini memiliki kesamaan yaitu sama-sama menekankan pada penguatan bidang keagamaan peserta didiknya. Meskipun ada kesamaan orientasi pendidikan karakter, tetapi implementasi pendidikan karakter melalui proses pembelajaran daring memiliki tantangan dan peluang yang berbeda-beda di masing-masing sekolah. Berikut ini merupakan bidang pelajaran keagamaan yang menjadi sarana penguatan pendidikan karakter di masing-masing sekolah.

Tabel 1. Kegiatan Penguatan Pendidikan Karakter

\begin{tabular}{|c|c|}
\hline Sekolah & Kegiatan Penguatan Karakter Religiositas \\
\hline SMA Al Ghurabaa & $\begin{array}{l}\text { - } \quad \text { Tadarus Al-Qur'an. } \\
\text { - Tahsin dan tahfidz Al-Qur'an untuk peserta didiknya } \\
\text { - Pembiasaan salat berjamaah }\end{array}$ \\
\hline $\begin{array}{l}\text { SMA Muhammadiyah } \\
11\end{array}$ & 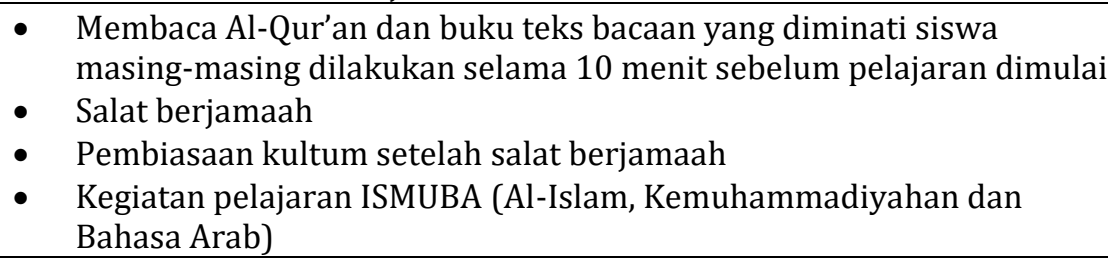 \\
\hline SMA Al Azhar 19 & $\begin{array}{l}\text { - } \quad \text { Program kelas Tahfidz dengan kegiatan camp tahfidz } \\
\text { - } \quad \text { masing perwalian kelas. } \\
\text { - } \quad \text { Kegiatan pelajaran AQUBA (agama Islam, Al-Qur'an, Bahasa Arab) } \\
\text { - } \quad \text { MAlat berjamaah } \\
\text { MABIT (malam bina iman dan takwa) }\end{array}$ \\
\hline
\end{tabular}

Sebagai sekolah berlabel Islam yang sudah berdiri sejak tahun 1981, fokus pendidikan karakter di SMA Al Ghurabaa bertumpu pada kegiatan tadarus Al-Quran yang dilakukan peserta didik dan guru sebelum memulai aktivitas belajar dan mengajar, salat berjamaah (Zuhur, Ashar, dan Salat Jumat). Berbagai kegiatan tersebut menjadi bagian rutin sekolah dalam membangun karakter religiositas peserta didiknya, karena memiliki fasilitas masjid yang terintegrasi di dalam lingkungan sekolah. Namun, dimasa pandemi COVID 19 sekarang, aktivitas pembelajaran daring dalam membangun karakter religiositas terkendala oleh daya dukung belajar peserta didik yang kurang memadai. 
Hasil penelitian ini menunjukkan bahwa tantangan implementasi pendidikan karakter melalui proses pembelajaran daring di SMA Al Ghurabaa dihadapkan pada persoalan minimnya fasilitas pendukung pembelajaran daring peserta didiknya. Karena mayoritas peserta didik datang dari kelas sosial bawah. Realitas ini dapat dilihat dari pekerjaan orang tua peserta didik di SMA Al Ghurabaa dominan bekerja pada sektor informal seperti, pekerja harian, tukang parkir, sopir pribadi, pedagang warung kelontong, dan buruh (Wawancara Guru, 2021).

Hasil wawancara bersama guru menyebutkan bahwa kegiatan tadarus secara daring cenderung tidak optimal, karena sebagian besar peserta didik memiliki keterbatasan kuota ataupun smartphone yang harus bergantian dengan anggota keluarganya. Di sini kemudian pendidikan karakter berbasis nilai religiositas melalui pembelajaran daring terkesan belum optimal, sebab tidak didukung oleh teknologi pembelajaran yang memadai. Narasi hasil temuan tersebut menandakan bahwa pembelajaran daring dimasa pandemi COVID 19 menjadi tantangan bagi sekolah seperti SMA Al Ghurabaa karena potensi dan peluang yang menjadi daya dukung implementasi pendidikan karakter yang utama di sekolah dominan dilakukan dengan cara konvensional.

Penjelasan di atas menegaskan bahwa potensi penguatan pendidikan karakter religiositas di SMA Al Ghurabaa dapat dilakukan dengan efektif melalui cara interaksi tatap muka (belajar konvensional), proses pembelajaran yang tidak perlu mengeluarkan biaya begitu besar. Oleh sebab itu, proses belajar dengan tatap muka atau interaksi langsung menjadi kunci penting pelaksanaan dan pembangunan karakter religiositas di SMA Al Ghurabaa. Akan tetapi, kondisi saat ini sudah berbeda, sejak masa pandemi, penguatan pendidikan karakter di sekolah melalui proses belajar yang serba digital dan online menemui kendala kekurangan biaya dan tidak memiliki kelengkapan alat pembelajaran pendukung.

Pada masa pandemi COVID 19, persoalan biaya dan alat pendukung pembelajaran peserta didik yang minim berdampak pada kurang bergairahnya proses penguatan nilai karakter religiositas di SMA Al Ghurabaa. Ketersediaan platform digital seperti, Google Meet dan Zoom Meeting yang dapat diakses secara gratis masih belum dapat dioptimalkan sebagai sarana interaksi langsung dalam proses pembelajaran untuk membangun karakter religiositas peserta didiknya. Meskipun platform digital dapat diakses gratis, namun penggunaan teknologi gratis itu sangat terkendala karena pemakaiannya terbatas dengan beberapa waktu saja. Kalaupun dapat diakali untuk terus meregistrasi akun, tentu akan menyulitkan proses belajar dan mengajar karena harus keluar-masuk akibat ganti akun (wawancara guru, 2021). Implikasinya, penguatan pendidikan karakter berjalan secara terbatas yaitu dengan cara memanfaatkan aplikasi gratis seperti WhatsApp Group. 
Selain persoalan di atas, penguatan karakter religiositas di SMA Al Ghurabaa juga dihadapkan pada persoalan kurangnya etos belajar peserta didiknya. Sehingga proses pembelajaran daring terkesan kurang menarik, dan jauh lebih menarik untuk bermain dari pada belajar. Pada masa pandemi ini, kesempatan bermain dirasa lebih longgar karena sekolah tidak membuka kelas tatap muka dengan peserta didik. Dengan keadaan demikian tentu yang dapat dilakukan pihak sekolah secara optimal hanya menegur peserta didik yang kerap tidak hadir. Perangkat teknologi gratis yang dapat diimplementasikan dalam proses belajar daring yang minim, karena gratis menjadi tantangan sekaligus peluang yang harus dimaksimalkan. Sekolah harus berupaya dengan maksimal untuk mencari peluang agar tetap dapat mengendalikan proses penanaman nilai karakter pada peserta didik agar tidak terjadi kondisi di mana siswa malah menjadi tidak terkendali akibat pandemi berkepanjangan ini.

Deskripsi tantangan implementasi dan peluang pembelajaran karakter di SMA Al Ghurabaa tentu berbeda dengan sekolah seperti SMA Muhammadiyah 11 yang terletak di Jalan Balai Pustaka Barat No. 2, Rawamangun-Jakarta Timur. Perbedaan tersebut dilatari oleh karakteristik sekolah dan keberadaan kelas sosial ekonomi peserta didiknya. Pada SMA Muhammadiyah 11 mayoritas peserta didik tergolong dari keluarga mampu atau dari keluarga kelas menengah. Realitas ini dapat dilihat dari pekerjaan orang tua siswa yang menyekolahkan anaknya di SMA Muhammadiyah 11 bekerja sebagai pengusaha, pegawai negeri senior, dan pemilik usaha (Wawancara, 2021). Tentunya, kondisi kelas sosial ekonomi keluarga peserta didik yang dominan mapan ekonominya sangat menentukan kiprah SMA Muhammadiyah 11, khususnya dalam pelaksanaan pendidikan karakter yang dilakukan secara daring.

SMA Muhammadiyah 11 sebagai lembaga pendidikan Islam yang sudah berdiri sejak tahun 1982, tampaknya memiliki kesiapan untuk beradaptasi dengan sistem pembelajaran daring. Sehingga implementasi pendidikan karakter religiositas yang sudah menjadi kegiatan rutinnya seperti, tadarus Al-Qur'an dan membaca buku teks sebelum kelas dimulai, kultum, salat berjamaah, kegiatan pembelajaran Al-Islam, Kemuhammadiyahan dan Bahasa Arab (ISMUBA) dan pemberian penghargaan dari pihak sekolah pada peserta didik berprestasi dapat tetap terlaksana. Selain itu, dimasa pandemi proses pembelajaran tambahan di luar sekolah seperti lembaga bimbel masih tetap berlangsung. Pada konteks ini kalangan peserta didik tidak kebingungan dan tidak banyak memberikan keluh kesah terhadap aktivitas belajarnya sehari-hari, para orang tua murid mendukung dengan fasilitas belajar lengkap (Wawancara Guru, 2021).

Pada SMA Muhammadiyah 11 penguatan pendidikan karakter religiositas melalui tradisi tadarus Al Quran membaca buku teks dan kultum tetap berlangsung seperti sediakala. Hanya saja konteks implementasi pembelajarannya dilakukan secara daring. Sama seperti halnya tradisi wisuda juga tetap berlangsung secara daring, karena kegiatan 
ini merupakan perayaan prestasi peserta didik yang sangat dinantikan orang tua peserta didik. Tradisi pemberian penghargaan pada peserta didik yang berprestasi tetap dilakukan lewat Zoom, sehingga tidak terdapat kendala dalam proses pelaksanaannya.

Berikutnya berkaitan dengan aspek penilaian pembelajaran di SMA Muhammadiyah 11 juga dapat dilakukan dengan optimal secara daring. Sebagai contoh, saat ujian keagamaan berlangsung, para siswa dengan hikmat melakukannya secara daring dan dibimbing oleh guru dengan serius. Realitas ini terjadi karena dukungan perangkat pembelajaran yang memadai (akun Zoom premium, laptop, dan smartphone yang mendukung proses pembelajaran). Kenyataan tersebut menjadikan penguatan pendidikan karakter religiositas tetap terlaksana. Karena pihak sekolah memiliki sumber daya yang memadai dalam melaksanakan proses belajar dan mengajar, serta para peserta didik memiliki kemampuan sumber daya untuk mengikuti proses belajar dengan sistem daring itu sendiri.

Selanjutnya, SMA Al Azhar 19 Ciracas-Jakarta Timur yang terbilang kelahirannya sebagai lembaga pendidikan berlabel Islam masih baru, karena baru berdiri sejak tahun 2016 (wawancara guru, 2021). Meskipun konteks pendiriannya masih baru, namun dalam proses pelaksanaan pendidikannya didukung oleh sarana dan prasarana pendidikan yang lengkap. Realitas ini dapat dilihat dari sarana dan prasarana yang dimilikinya yaitu: akses internet di sekolah, sumber daya listrik yang memadai, perpustakaan, dan dukungan laboratorium praktik yang memadai. Secara umum karakteristik SMA Al Azhar 19 tidak jauh berbeda dengan SMA Muhammadiyah 11. Di mana para peserta didiknya datang dari latar belakang orang tua yang sudah mapan secara ekonomi dan pekerjaannya. Sehingga daya dukung proses belajar dan mengajar tidak pernah menjadi persoalan. Oleh sebab itu, dalam situasi pandemi COVID 19 mereka tetap bisa melakukan proses pembelajaran secara efektif.

Sebagai lembaga pendidikan berlabel Islam, penguatan pendidikan karakter religius di SMA Al Azhar 19 bertumpu pada program keagamaan yang sistematis (di dalamnya ada ikrar, tadarus Al-Qur'an), salat Dhuha, kultum, doa dan zikir, azan, MABIT (malam bina iman dan takwa), peserta didik wajib mengisi khotbah Jumat, wisuda, menyisipkan muatan IMTAQ (iman dan takwa) di setiap materi yang disampaikan di dalam RPP, pelajaran agama Islam, Al-Qur'an, Bahasa Arab (AQUBA) serta penghargaan pada murid yang berprestasi. Sebagai contoh kebiasaan doa dan zikir sehabis melaksanakan salat zuhur maupun asar, di mana dipimpin oleh salah satu murid yang sejak awal tahun ajaran sudah dibuatkan jadwalnya.

Dimasa pandemi COVID 19, implementasi pendidikan karakter religiositas dilakukan melalui berbagai kegiatan keagamaan berlangsung di Zoom (seperti; tadarus, kultum, literasi buku teks referensi dan MABIT). Sebagaimana dikatakan oleh seorang guru bahwa dimasa pandemi COVID 19 implementasi pendidikan karakter religiositas tetap 
dilakukan dengan kegiatan MABIT virtual. Jadi, kegiatan MABIT virtual dilakukan secara perjenjang atau perangkatan. Kegiatan tersebut dilakukan sehabis asar, yang dimulai dengan acara sambutan pembacaan kalam ilahi dari peserta didik sampai kepada materimateri yang disampaikan oleh bapak dan ibu guru. Pada akhir kegiatan MABIT, peserta didik dan orang tuanya mengikuti salat tahajud berjamaah (wawancara guru, 2021). Dari temuan tersebut dapat disimpulkan bahwa proses pembelajaran daring tidak menyulitkan sekolah ataupun peserta didik dan orang tuanya, karena dukungan sumber daya yang mumpuni menjadi faktor penting pendukung dalam penguatan pendidikan karakter religiositas di sekolah tersebut.

Tabel 2. Tantangan dan Peluang berdasarkan karakteristik Sekolah

\begin{tabular}{|c|c|c|}
\hline Sekolah & Tantangan & Peluang \\
\hline $\begin{array}{l}\text { SMA } \\
\text { Al Ghurabaa }\end{array}$ & 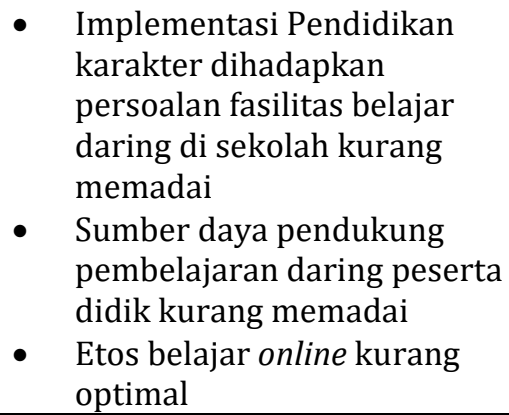 & $\begin{array}{l}\text { Lingkungan sekolah terintegrasi masjid megah, } \\
\text { sehingga potensi dan peluang penguatan } \\
\text { pendidikan karakter dominan dilakukan } \\
\text { dengan sistem pendidikan konvensional (tatap } \\
\text { muka) }\end{array}$ \\
\hline $\begin{array}{l}\text { SMA } \\
\text { Muhammadiyah } \\
11\end{array}$ & $\begin{array}{l}\text { - } \\
\text { kenguatan pendidikan } \\
\text { kendala teknis, seperti siswa } \\
\text { bangun siang dan telat } \\
\text { masuk kelas online saja. } \\
\text { - Mengontrol kedisiplinan } \\
\text { siswa dalam proses } \\
\text { pembelajaran daring }\end{array}$ & $\begin{array}{l}\text { - Kemampuan beradaptasi dengan } \\
\text { teknologi tinggi } \\
\text { - Memiliki learning management system } \\
\text { (LMS) mandiri dengan link http: //pjj. } \\
\text { smasmuh11jakarta.sch.id/index.php/login } \\
\text { - Akses platform digital premium (Zoom } \\
\text { berbayar) }\end{array}$ \\
\hline $\begin{array}{l}\text { SMA Al Azhar } \\
19\end{array}$ & $\begin{array}{l}\text { Dominan dihadapkan pada } \\
\text { kendala yang bersifat teknis } \\
\text { seperti, kendala sinyal } \\
\text { karena hujan, terlambat } \\
\text { masuk kelas online }\end{array}$ & $\begin{array}{ll}\text { - } & \text { Orang tua peserta didik terlibat dalam } \\
\text { - } & \text { penguatan karakter peserta didik } \\
\text { Penguatan pendidikan karakter melalui } \\
\text { kegiatan virtual } \\
\text { - } \\
\text { Memiliki layanan program sistem } \\
\text { pembelajaran online terpadu (SIDU) } \\
\text { dengan link sidu.smaialazhar19.sch.id } \\
\text { - } \\
\text { Guru dituntut kreatif dalam proses } \\
\text { pembelajaran keagamaan }\end{array}$ \\
\hline
\end{tabular}

Sumber: diolah dari data lapangan (2021)

Berdasarkan data tabel 2 di atas dapat diketahui bahwa tantangan dan peluang implementasi pendidikan karakter religiositas sebagai branding sekolah, baik di SMA Al Ghurabaa, SMA Muhammadiyah 11, maupun di SMA Al Azhar 19 memiliki perbedaan. Sebagaimana temuan di SMA Al Ghurabaa, Implementasi Pendidikan karakter religiositas dihadapkan persoalan fasilitas belajar daring di sekolah yang kurang memadai. Realitas ini dapat dilihat dari terbatasnya ketersediaan platform digital untuk pembelajaran daring seperti LMS, dan Zoom premium berbayar tidak dimiliki sekolah. 
Kemudian penguatan pendidikan karakter religiositas melalui proses pembelajaran daring juga terkendala dengan sumber daya pendukung pembelajaran daring peserta didik yang kurang memadai, sehingga etos belajar daring sebagai sarana membangun karakter religiositas kurang tercapai secara optimal. Narasi kendala pembelajaran daring di SMA Al Ghurabaa menandakan peluang atau potensi yang dominan dapat dilakukan untuk penguatan pendidikan karakter religiositas peserta didik bertumpu pada strategi belajar tatap muka, karena memiliki masjid yang terintegrasi dengan lingkungan sekolah. Sehingga praktik penguatan pendidikan karakter religiositas dapat dilakukan dengan optimal.

Berbeda halnya dengan SMA Muhammadiyah 11 dan SMA Al Azhar 19 yang notabene memiliki kesiapan untuk melaksanakan pembelajaran daring, maka mereka secara otomatis dapat melaksanakan pendidikan karakter berbasis religiositas melalui proses belajar dan mengajar yang efektif. Dalam konteks ini, SMA Muhammadiyah 11 dan SMA Al Azhar 19 cenderung mampu menangkap peluang melalui kemampuannya untuk beradaptasi dengan teknologi. Realitas ini dapat dilihat dari inisiatif dua sekolah tersebut untuk membuat learning management system (LMS) yang dibiayai dan dibuat secara serius untuk mendukung proses pembelajaran daringnya.

SMA Muhammadiyah 11 dan SMA Al Azhar 19 memiliki peluang untuk terus memajukan teknologi pembelajaran. Sehingga baik sekolah dan komite sekolah tidak khawatir peserta didik ketinggalan pelajaran, karena proses belajar dengan menggunakan e-learning yang menggunakan teknologi mutakhir dapat terus dilakukan dengan dukungan sumber daya finansial sekolah dan dukungan orang tua peserta didik yang tidak mempersoalkan biaya demi masa depan anak-anak mereka. Kemudian berkaitan dengan konteks tantangan yang kerap muncul dalam implementasi pendidikan karakter berbasis religiositas di SMA Muhammadiyah 11 dan SMA Al Azhar 19 yaitu berkenaan dengan kendala teknis seperti, siswa bangun siang dan telat masuk kelas online, kendala jaringan internet karena hujan dan kendala mengontrol kedisiplinan siswa dalam proses pembelajaran daring seperti siswa tidak menunjukkan kameranya saat tadarus, sehingga guru tidak melihat kondisi belajar peserta didiknya.

\section{B. Pembahasan}

Pendidikan karakter yang populer diperbincangkan hari ini pada dasarnya sudah disemaikan dalam wacana dan pelaksanaan pendidikan baik sebelum maupun sesudah kemerdekaan Indonesia. Pendidikan bukanlah sekedar transfer of knowledge dengan tujuan untuk mengasah kecerdasan kognitif, tetapi ia merupakan sarana penting untuk mengasah kecerdasan budi/karakter, karena membangun budi pekerti/karakter yang baik dan kokoh dapat mewujudkan kepribadian/karakter yang mengalahkan nafsu dan tabiat-tabiat bengis, murka, pemarah, kikir, keras, dan tabiat buruk lainnya. 
Secara konseptual dan praktik, pendidikan karakter dapat kita pahami sebagai sebuah pendekatan untuk memperkenalkan standar etika dan moral tentang baik dan buruk. Sebagaimana dijelaskan oleh Megawangi bahwa pendidikan karakter merupakan sarana untuk menanamkan standar moral universal seperti sayang kepada sesama, berlaku jujur, menolong orang, dan bertanggung jawab (Megawangi, 2009). Senada dengan Lickona menjelaskan bahwa pendidikan karakter merupakan upaya yang direncanakan untuk membantu orang memahami, peduli, dan bertindak atas nilai-nilai etika dan moral. Artinya, pendidikan karakter mengajarkan kebiasaan berpikir dan berbuat ke arah pada kehidupan yang bekerja bersama-sama sebagai keluarga, teman, tetangga, masyarakat, dan bangsa (Lickona dkk., 2007).

Berdasarkan narasi di atas dapat diketahui bahwa implementasi pendidikan karakter memiliki relasi yang kuat dengan nilai-nilai religiositas. Oleh sebab itu, pelaksanaan pendidikan karakter berbasis pada nilai religiositas menjadi penting ditanamkan dan dikembangkan di arena sekolah. Pendidikan karakter dapat efektif membangun kepribadian peserta didik jika dilaksanakan dengan pendampingan secara terpadu antara guru dan peserta didik di ruang kelas (Santika, 2020). Namun, pada saat ini upaya pendampingan dan pertemuan tatap muka di dalam arena ruang kelas belum dapat dilaksanakan. Sehingga penguatan pendidikan karakter berbasis religiositas ini dituntut untuk mampu memanfaatkan teknologi sebagai sarana untuk melaksanakannya.

Pendidikan karakter dan pemanfaatan teknologi bukan sekedar hanya untuk melihat kondisi pandemi COVID 19 saat ini, tetapi penguatan pendidikan karakter yang saat ini mulai mengoptimalkan basis teknologi sudah selayaknya dipahami sebagai agenda pembelajaran masa mendatang. Argumentasi tersebut penting untuk diketengahkan, karena banyak sekolah hanya memanfaatkan teknologi seadanya dan tidak mau bergerak pada penggunaan teknologi secara maksimal. Kondisi tersebut dilatari oleh anggapan bahwa pandemi COVID 19 dapat berakhir dan situasi kembali normal dan tidak perlu lagi berkutat pada teknologi, karena ke depan proses belajar akan normal dengan proses interaksi. Tentunya pandangan demikian keliru.

Kehidupan manusia secara sosiologis ke depan adalah bagaimana memanfaatkan teknologi dalam kehidupan sehari-hari. Tentu masing-masing sekolah memiliki tantangan dan peluang dalam menggunakan teknologi untuk mengantarkan para peserta didik agar lebih mengenal teknologi bukan sebagai peserta didik yang minim pengetahuan teknologi atau dengan istilah "gaptek" proyeksi pengenalan teknologi masa depan akan sangat berguna bagi peserta didik terutama menghadapi dunia setelah sekolah. Mereka jika terbiasa menggunakan teknologi akan dapat bertahan hidup meraih cita-cita, akan tetapi bagi peserta didik yang jauh dari aspek pengenalan terhadap teknologi akan tertinggal dengan orang lain yang memiliki pemahaman tinggi bidang teknologi. 
Pada konteks kekinian sekolah harus mampu melihat peluang ke depan. Proyeksi penggunaan teknologi harus dipandang jauh ke depan, di mana tidak ada batas waktu, sehingga jika kemudian manusia dihadapkan oleh kondisi pandemi selain COVID-19, sarana dan prasarana sekolah sudah siap dengan bekerjanya teknologi yang sudah dikembangkan saat ini dan tidak perlu lagi guru merasa kebingungan serta bagi guru yang masih gaptek atau gagap teknologi,, mungkin kondisi ini merupakan peluang penting untuk mempelajari sendi-sendi teknologi agar ke depan sudah semakin cakap dalam menerapkan proses pembelajaran e-learning.

Kontekstualisasi penguatan pendidikan karakter religiositas dengan penggunaan teknologi dapat dilihat dari sekolah seperti SMA Muhammadiyah 11 dan SMA Al-Azhar 19. Berbekal modal kepemilikan LMS di kedua sekolah tersebut, maka penerapan teknologi blended learning merupakan jalan terbaik terutama karena faktor sekolah yang secara sumber daya mampu baik dari segi finansial dan dukungan orang tua murid. Sehingga sudah seyogyanya kedua sekolah tersebut melihat teknologi pembelajaran sebagai capaian masa depan dan harus menjadi standar pembelajaran disekolah tersebut.

Pada dasarnya teknologi pembelajaran akan memberikan peluang-peluang masa depan dan efektivitas pembelajaran kepada seluruh peserta didik dimasa yang akan datang. Dahulu mungkin kita melihat bahwa sekolah online dianggap kurang memadai dan juga banyak orang mengira sekolah tersebut kurang baik lantaran proses interaksi tidak pernah dilakukan dan dikhawatirkan karakter anak didik tidak terbentuk karena sekolah dianggap bebas. Kondisi itu berbanding terbalik, peran teknologi yang semakin mumpuni dan canggih saat ini telah memutarkan fakta dan mindset masyarakat luas bahwa hanya dengan pembelajaran berbasis teknologi saat inilah proses pembelajaran dapat bertahan dan berkembang. Pendidikan dengan interaksi tatap muka hanya sebagai aktivitas penopang dari pembelajaran daring (online).

Kenyataan tersebut harus diterima masyarakat dalam kondisi pandemi sekarang ini. Tentunya bagi sekolah seperti SMA Al-Ghurabaa kondisi pandemi merupakan agenda penting dalam penguatan pembelajaran karakter berbasis teknologi murah serta tepat guna. Banyak elemen teknologi yang bisa dimanfaatkan dengan biaya murah hanya dengan memanfaatkan internet sebagai penunjang proses pembelajaran, meski demikian internet juga masih dipandang sebagai barang yang menyusahkan orang tua atas kondisi finansial mereka. Selain itu bagi SMA Al-Ghurabaa tentunya kondisi pandemi ini adalah bagaimana para guru diajarkan untuk memanfaatkan teknologi semaksimal mungkin supaya pembelajaran berbasis teknologi sebagai agenda pembelajaran masa depan dapat dirintis dan dicapainya.

Tentunya konsepsi teknologi sebagai jawaban atas keberlangsungan pendidikan masa depan harus menjadi agenda pada tingkat paling atas yang tidak semata 
mengembangkan sekolah. Terutama Kementerian pendidikan dan Kebudayaan Riset dan Teknologi RI untuk melihat proyeksi teknologi pembelajaran sebagai agenda masa depan dan mendorong sekolah yang notabene adalah sekolah kurang mampu agar mendapat dukungan baik dalam bentuk materiil maupun non materiil seperti pelatihan teknologi dan penyediaan teknologi pembelajaran dengan dana Negara. Sementara pada tataran sekolah seperti SMA Muhammadiyah 11 dan Al-Azhar 19 yang notabene sudah berkembang, mereka dapat berkembang menuju sekolah dengan basis teknologi agar dapat menjadi rujukan bagi sekolah lain yang belum berkembang untuk menunjukkan proses penerapan teknologi pembelajaran di sekolah. Hubungan simbiosis antar sekolah ini menjadi penting dan saling mendukung satu sama lain.

\section{Kesimpulan}

Berdasarkan hasil temuan penelitian ini dapat disimpulkan bahwa pelaksanaan pendidikan karakter yang coba dikembangkan di SMA Al Ghurabaa, SMA Muhammadiyah 11, dan SMA Al Azhar 19 yang menjadi locus riset ini sama-sama mengedepankan nilai keagamaan. Penguatan nilai agama menjadi wadah penting bagi pendidikan karakter di tiga sekolah tersebut. meskipun penguatan nilai agama menjadi wadah penting, tetapi implementasi pendidikan karakter di masa pandemi memiliki tantangan yang beragam pada tiap sekolah serta pengalaman sekolah dalam menjalani pembelajaran karakter berbasis digital melalui media daring. Dengan upaya memahami bahwa perkembangan teknologi harus disikapi sebagai orientasi masa depan, maka secara tidak langsung kita melihat bahwa pendidikan telah sigap dan adaptif dalam menghadapi bencana seperti pandemi COVID-19 yang terjadi hari ini serta sebagai bekal untuk menghadapi pandemi berikutnya.

\section{Daftar Pustaka}

Agustina, R. D. (2020). Optimalisasi Peran Orang Tua Dalam Pendidikan Karakter Siswa Pada Masa Pandemi COVID-19. "Bangkit dari Pandemi Menuju Hasil Penelitian dan Pengabdian yang Berdampak."WEBINAR NASIONAL STKIP PGRI JOMBANG.

Apriyanti, N., \& Burhendi, F. C. A. (2020). ANALISIS EVALUASI PEMBELAJARAN DARING BERORIENTASI PADA KARAKTER SISWA. PROSIDING SEMINAR DAN DISKUSI PENDIDIKAN DASAR. http://journal.unj.ac.id/unj/index.php/psdpd/article/view/17760

Azra, A. (2019). Pendidikan Islam: Tradisi dan Modernisasi di tengah Tantangan Milenium III. Prenada Media.

Jati, W. R. (2016). Globalisasi dan Kemiskinan Desa: Analisa Struktur Ekonomi Politik Pedesaan. Jurnal penelitian politik, 11(2), 10.

Kusumaningrum, B., Kuncoro, K. S., Arigiyati, T. A., \& Trisniawati. (2020). Pendampingan Orangtua Dalam Pembelajaran Daring Di Sekolah Dasar: : INVENTA: Jurnal Pendidikan Guru Sekolah Dasar, 4(2), 142-150. https://doi.org/10.36456/inventa.4.2.a2607 
Lickona, T., Schaps, E., \& Lewis, C. (2007). CEP's Eleven Principles of Effective Character Education. Dalam Character Education Partnership. Character Education Partnership. https://eric.ed.gov/?id=ED505086

Lubis, H. (2008). Pertumbuhan SMA Islam unggulan di Indonesia: Studi tentang strategi peningkatan kualitas pendidikan. Badan Litbang dan Diklat, Departemen Agama RI.

Mutrofin. (2009). Mengapa mereka tak bersekolah?: Evaluasi program kewajiban belajar. Laksbang Pressindo.

Noer, D. (1996). Gerakan Modern Islam Di Indonesia 1900-1942. LP3ES.

Ramdliyah, N.-. (2020). REVITALISASI PEMBINAAN PENDIDIKAN KARAKTER SANTRI UNTUK MEMPERBAIKI DEGRADASI MORAL GENERASI MILENIAL. Al-Tarbawi AlHaditsah: Jurnal Pendidikan Islam, 5(2), Article 2. https://doi.org/10.24235/tarbawi.v5i2.6562

Megawangi, R. (2009). Pendidikan Karakter: Solusi Tepat untuk Membangun Bangsa. Heritage Foundation.

Rosita, E., Erihadiana, M., Rochman, C., \& Mansyur, A. S. (2020). Kompetensi profesional dan karakteristik guru pada masa pandemik. Ta'dibuna: Jurnal Pendidikan Islam, 9(2), 314-320. https://doi.org/10.32832/tadibuna.v9i2.3124

Saihu, S., \& Mailana, A. (2019). Teori pendidikan behavioristik pembentukan karakter masyarakat muslim dalam tradisi Ngejot di Bali. Ta'dibuna: Jurnal Pendidikan Islam, 8(2), 163-176. https://doi.org/10.32832/tadibuna.v8i2.2233

Santika, I. W. E. (2020). Pendidikan Karakter pada Pembelajaran Daring. Indonesian Values and Character Education Journal, 3(1), 8-19. https://doi.org/10.23887/ivcej.v3i1.27830

Siswanto, A. (2020). PENDIDIKAN POLITIK BERBASIS KOMUNITAS Di JAKARTA UTARA (Studi Kasus: Pendidikan Politik JRMK Untuk Warga Miskin Jakarta Utara). Hermeneutika : Jurnal Hermeneutika, 6(1), Article 1. https://doi.org/10.30870/hermeneutika.v6i1.7517

Winaya, I. M. A. (2020). PENGEMBANGAN NILAI-NILAI KARAKTER ANAK PADA PEMBELAJARAN JARAK JAUH DI MASA PADEMI COVID-19 DENGAN BERBANTU LEMBAR KEJA SISWA BERBASIS PROYEK. Jurnal Pendidikan Kewarganegaraan Undiksha, 8(3), 124-135. https://doi.org/10.23887/jpku.v8i3.28612

Yuliana, N., R, M. D., \& Fahri, M. (2020). MODEL PENDIDIKAN HOLISTIK BERBASIS KARAKTER DI SEKOLAH KARAKTER INDONESIA HERITAGE FOUNDATION. EduHumaniora / Jurnal Pendidikan Dasar Kampus Cibiru, 12(1), 15-24. https://doi.org/10.17509/eh.v12i1.15872

Yuniarto, P. R. (2016). Masalah Globalisasi di Indonesia: Antara Kepentingan, Kebijakan, dan Tantangan. Jurnal Kajian Wilayah, 5(1), 67-95. https://doi.org/10.14203/jkw.v5i1.124 